\title{
The Effects of Exchange Rate and Interest Rate Exposure on the Stock Returns and Volatility of Turkish Insurance Companies
}

\section{Döviz Kuru ve Faiz Oranı Varlığının Türk Sigorta Şirketlerinin Stok Dönüşleri ve Volatilitesi Üzerindeki Etkileri}

\author{
İsmail Erkan ÇELIK ${ }^{1}$
}

\begin{abstract}
This study examines the impact of exchange rate and interest changes on stock returns and volatility of Turkish insurance companies using the EGARCH model for the period of 01/01/2009 to 15/04/2020. The results show: (i) while interest rate has a negative and significant effect on the conditional stock return, its effect on the volatility of stock returns of insurance companies is limited; (ii) however, the exact opposite is true for the exchange rate risk. The exchange rate risk exerts an important impact on the volatility of insurance stock returns but it has no effect on the mean stock returns of insurance companies; (iii) the findings also indicate that the volatility of insurance stock returns are highly persistent over time and they are more sensitive to old news than recent surprises; (iv) positive and negative news have an asymmetric effect on volatility implying that positive innovations (good news such as a market) have a larger impact on current conditional variance (current volatility of returns) than negative innovations (bad news such as market stagnation) of the same magnitude; (v) finally, the volatility of insurance portfolio's and insurance companies' stock returns has risen significantly during the financial crisis of 2008 compared to the rest of the sample period.
\end{abstract}

Keywords: Volatility, Insurance companies, EGARCH model, Exchange rate risk, Interest rate risk

JEL Classification: D51, F3, G32
DOI: 10.26650/ISTJECON2020-0013 1Dr., Doğuş University, Faculty of Economics and
Administrative Sciences, Department of Economics, İstanbul, Turkey

ORCID: A.Ö.A. 0000-0002-2274-0750

Corresponding author/Sorumlu yazar: İsmail Erkan ÇELIK,

Doğuş University, Faculty of Economics and Administrative Sciences, Department of Economics, İstanbul, Turkey

E-mail/E-posta: ismailerkancelik@gmail.com

Submitted/Başvuru: 02.05.2020

Accepted/Kabul: 09.05.2020

Citation/Atıf: Celik, I. E. (2020). The effects of exchange rate and interest rate exposure on the stock returns and volatility of Turkish insurance companies. Istanbul iktisat Dergisi - Istanbul Journal of Economics, 70(1), 141-161. https://doi.org/10.26650/ISTJECON2020-0013 


\section{Introduction}

This study aims to investigate the impact of exchange rate and interest rate risk on the stock returns and volatility of Turkish insurance companies. The insurance sector and insurance companies contribute significantly to the overall performance of the national economy through spreading risk among a large number of economic agencies, providing safety, security, and support to individuals, families and businesses, generating long-term financial resources, and promotes economic growth. Due to its important role in the economy, an analysis of insurance company returns is of great interest to policy makers, regulatory agencies, investors, portfolio managers, and researchers on the subject.

There are a number of theoretical channels through which changes in exchange rate and interest rate affects stock returns. These channels can be enumerated (Kasman, Vardar, \& Tunç, 2011; Olugbode, El-Masry, \& Pointon, 2014) as: the intertemporal capital pricing model of Merton (1973); the nominal contracting hypothesis of Kessel (1956), Bach and Ando (1957), and French, Ruback, and Schwart (1983); the maturity mismatch hypothesis of Flannery, Hameed, and Harjes (1997); linkages between the revenues, costs and profitability of insurance companies and the unexpected changes in interest rates and exchange rates by Saunders and Yourougou (1990), Yourougou (1990).

Although there are various studies on the subject about the banking sector, the empirical studies on the impact of the exchange rate and interest rate on stock returns and volatility of insurance companies' stock prices are limited in number. Those studies examined the dynamic time-varying nature of insurance stock returns include Brewer, Carson, Elyasiani, Mansur, and Scott (2007), Jensen, Johnson, and McNamara (2009), Dikko, Asiribo, and Samson (2015), and Papadamou and Siriopoulos (2014). Although these studies analysed thoroughly the effects of exchange rate and interest rate exposure on stock returns of insurance companies, they overlooked the effects of exchange rate, interest rate, and the global financial crisis of 2008 on the volatility of stock returns in the insurance sector. 
In the light of these discussions, this study attempts to investigate the impact of exchange rate and interest rate on stock returns and volatility of stock returns for the Turkish insurance sector and insurance companies paying close attention to the effect of the global financial crisis of 2008 on volatility. The remainder of the study is organized as follows. Section 2 provides a brief review of the literature on the impact of interest rate and exchange rate risk on stock returns of insurance companies. Section 3 introduces the empirical model and the relevant data. Section 4 presents the empirical findings of the study. Section 5 concludes.

\section{Literature Review}

There is vast empirical literature on the impact of interest rates and exchange rates on the sock returns of financial institutions. These studies employed the GARCH type models to capture the volatility and time varying nature of stock prices. However, the existing literature focused heavily on the stock return of banking institutions (Engle, Ng, \& Rothschild, 1990; Mansur \& Elyasiani, 1995; Flannery et al., 1997; Elyasiani \& Mansur, 1998; Hooy, Tan, \& Md Nassir, 2004; Ryan \& Worthington, 2004; Elyasiani \& Mansur, 2005; Sehgal \& Agrawal, 2017; Özçiçek, 1997; Kasman et al., 2011; Ekinci, 2016; Çiçek, 2014; Çelik, 2019).

However, there is only a limited number of studies that investigate the impact of interest rates and exchange rates on the sock returns of insurance institutions in the relevant literature. The first study on the relationship between exchange rate, interest rate and stock return of insurance companies using the GARCH type model was conducted by Brewer et al. (2007). Researchers in this study examined the impact of interest rate on monthly stock returns for 60 publicly traded American life insurance companies over the period of 1975 to 2000. They have estimated a generalized autoregressive conditionally heteroskedastic in the mean (GARCH (1.1)-M) model for large firm, medium firm and small firm portfolios over the whole sample period and sub-periods. Estimation results indicated that the equity values of life insurance companies in the USA are more sensitive to long-term interest rates than short-term interest 
rates and that interest sensitivity varies across sub-periods and across risk based and size-based portfolios.

Hamadu and lbiwoye (2010) investigated the volatility of the daily returns of Nigerian insurance stocks using the TARCH, GARCH and Exponential Generalized Autoregressive Conditional Heteroskedastic (EGARCH) models. Among several variants of heteroskedastic conditional volatility models the post estimation evaluations indicated that the EGARCH provides a more suitable modelling framework for evaluating risk volatility of Nigerian insurance stocks.

In another study, Papadamou and Siriopoulos (2014) examined the sensitivity of the stock return of life insurance companies to interest rates in the UK on using the GARCH-M model. The result of the study indicated that while the sensitivity of insurance stock returns to change in the level and volatility of interest rates increased in the period before the Bank of England (BoE) was granted operational independence, it decreased after the establishment of the Monetary Policy Committee (MPC) in May 1997.

In their study, Dikko et al., (2015) examined the impact of abrupt shifts in the volatility of Nigerian insurance stock returns using seven symmetric and five asymmetric GARCH type models with dummy variables. The results showed that the ARCH (1) model is the most suitable among the twelve competing volatility models for the Nigerian insurance stock returns. The results also showed that the scale of persistency in volatility of insurance stock returns declined when the shift dummies incorporated into variance equation of the returns model.

Different from the previous studies, Carson, Elyasiani, and Mansur (2008) examined the market risk and interest rate risk for three insurer segments (accident and health, life, and property and casualty insurers), and searched for interdependencies in stock returns and volatility spillovers across these different segments of insurance industry using a system GARCH model. The results showed that there are significant interdependencies in stock returns but no significant volatility spillover across the three segments of the insurance industry. They have also 
found that market risk is the greatest for accident and health $(A \& H)$ insurers, followed by life (Life) insurers and property and casualty $(P \& C)$ insurers, while interest rate sensitivity is greater for Life insurers than that for $A \& H$ and for $P \& C$ insurers.

Mouna and Anis (2016) estimated the impact of market, interest rate, and exchange rate risks on the stock returns in the insurance sector using the data from eight different countries (European countries, the US, and China) over the period 2006-2009. They have employed a four-variate GARCH-in-mean model and volatility spillovers in their analysis. The results showed that there is significant relationship between the stock market returns, interest rate, exchange rate and stock returns of insurance companies during the crisis. Furthermore, the results indicated that there exist significant volatility spillovers from market return, interest rate, exchange rate to insurance stock returns in both European and the US companies during the financial crisis.

Jensen et al. (2019) examined the US insurance company stock returns under different funding conditions using the constant conditional correlation multivariate GARCH (CCC-MGARCH) model for the period of January 1966 to December 2015. The results of the study showed that constrained funding environments reduce insurance company stock returns and this effect varies across insurer type. The negative effect of constrained funding environment is strongest during the first 3 months and for life and health insurers.

Mechri, Hamad, Peretti, and Charf (2018) aim to identify the impact of exchange rate volatility on the fluctuations of stock markets prices, considering two countries from Middle East and North Africa (MENA) zone. In the study, they integrate assorted determinants of stock market indices that have not been used simultaneously before, and they spread out their research period up to 15 . The $\mathrm{GARCH}$ model is employed. The results show that exchange rate volatility have a significant effect on stock market fluctuations.

The paper of De Sousa, Noriller, Huppes, Vaz Lopes, and Meurer (2018) aims to verify the relation between the macroeconomic indicators with the stock return (SR) 
in public companies of the finance and insurance sector from Latin America. Data was analyzed from 2010 to 2017 through dynamic panel analysis via Generalized Method of Moments (GMM) by two approaches: Arellano-Bond e System. Results pointed that the stock return showed a positive relation with exchange rates, but a negative relation with Gross Domestic Products. It is concluded that macroeconomic variables interfere with the shareholder return of companies in the finance and insurance sector.

Katusiime (2019) investigates the impact of commodity price volatility spillovers on financial sector stability. Specifically, the study investigates the spillover effects between oil and food price volatility and the volatility of a key macroeconomic indicator of importance to financial stability: the nominal Uganda shilling per the United States dollar (UGX/USD) exchange rate. Volatility spillover is examined using the Generalized Vector Autoregressive (GVAR) approach and Multivariate Generalized Autoregressive Conditional Heteroskedasticity (MGARCH) techniques, namely the dynamic conditional correlation (DCC), constant conditional correlation (CCC), and varying conditional correlation (VCC) models. Overall, the results of both the GVAR and MGARCH techniques indicate low levels of volatility spillover and market interconnectedness except during crisis periods, at which point cross-market volatility spillovers and market interconnectedness sharply and markedly increased.

\section{Model and Data}

As seen from the review of the literature, modelling stock returns of insurance companies requires special attention due to the stylised facts of the insurance data. The insurance stock returns can be characterised by their highly volatile nature. Volatility clustering and leverage effects are two important properties of these series. The volatility of return series is not constant over time and turbulent (high-volatility) sub-periods are followed by tranquil (low-volatility) periods for these series. Furthermore, the impact of past positive and negative shocks on the current volatility of returns is asymmetric. That is, negative returns (corresponding to price decreases) tend to increase volatility by a larger amount than positive returns (price increases) of 
the same magnitude (leverage effect) (Francq \& Zakoian, 2019) such series are called conditionally heteroskedastic series. Any satisfactory statistical model for insurance stock returns must be able to capture these characteristics of data.

The models introduced in the econometric literature to account for the volatile nature of insurance stock return series involve the GARCH-type models. The first model that handles volatility in time series is autoregressive conditionally heteroscedastic (ARCH) models introduced by Engle (1982). Later, Bollerslev (1986) extended the ARCH Model to the GARCH Model. The key property of these models involves modelling the conditional variance as a linear function of the squared past innovations. However, the standard GARCH models have two drawbacks (Chang, Hsu, \& McAleer, 2014). First, they put the positivity constraints on the GARCH coefficients which lead to technical difficulties for the inference. Second, the classical GARCH model assumes that the impact of positive and negative shocks is symmetrical. That is, past positive and negative innovations have the same effect on the current volatility.

In the light of these discussions, this study employs the EGARCH methodology in the analysis of stock returns in the insurance sector. The empirical insurance stock return model in where its conditional variance has EGARCH specification is provided in Equations 1 and 2. As seen from Equation (1), the conditional mean of insurance companies' stock returns is modelled as a function of three risk factors, exchange rate, interest rate and market risk respectively. The EGARCH specification of the conditional variance of insurance stock returns is given in Equation (2).

As noted in Equation (2), the conditional variance equation is an extended version of EGARCH specification. Considering the fact that exchange rate and interest rate affect not only the mean but also the volatility of stock returns (Kasman et al., 2011), we included the exchange rate volatility $\left(E R^{2}\right)$ and interest rate volatility $\left(I R^{2}\right)$ variables into the conditional variance equation given in Equation (2) below. Furthermore, we added a dummy variable that takes ones for the period of the global financial crisis and zeros otherwise to the conditional 
variance specification in Equation (2). As explained in the literature review section, Dikko et al., (2015) found out that the scale of persistency in the volatility of insurance stock returns declined when the shift dummies incorporated into variance equation of the returns model. For this reason, we added a crisis dummy variable to the variance equation to check whether the 2008 financial crisis affected the parameter estimates in Equations (1) and (2).

\section{Conditional mean specification}

$$
\begin{array}{r}
R_{t}=a_{0}+a_{1} E R_{t}+a_{2} I R_{t}+a_{3} M R_{t}+\varepsilon_{t} \\
\varepsilon_{t} \mid I_{t-1} \sim N\left(0, h_{t}\right)
\end{array}
$$

where $R_{t,} E R_{t,} I R_{t}$ and $M R_{t}$ represents daily stock price returns, percentage change in daily exchange rate, percentage change in interest rates, market returns at time. $\varepsilon_{t}$ represents normally distributed error terms with mean zero and the conditional variance of $h_{t}$.

\section{Conditional variance specification: EGARCH}

Nelson (1991) proposed an alternative specification for the conditional variance that does not require nonnegativity constraints and that allows for the asymmetric effect of news. This model is known as the EGARCH model. The EGARCH variance equation can be written as:

$$
\ln \left(h_{t}\right)=\omega+\alpha\left|\frac{\varepsilon_{t-1}}{\sqrt{h_{t-1}}}\right|+\gamma \frac{\varepsilon_{t-1}}{\sqrt{h_{t-1}}}+\beta \ln \left(h_{t-1}\right)+\delta E R^{2}+\theta I R^{2}+\lambda D_{\text {crisis }}
$$

\section{Where}

$\ln \left(h_{t}\right)$ represents the logarithm of conditional variance at time t. Since the conditional variance, $\ln \left(h_{t}\right)$, is modelled in log-linear form, regardless of the magnitude of $\ln \left(h_{t}\right)$, it will always be positive requiring no artificially impose nonnegativity constraints on the model parameters. Hence, it is permissible for the coefficients to be negative. 
$\omega$ is the intercept for the variance and indicates the extent of conditional variance. It is the time independent component of volatility.

$a$ shows the presence of volatility clustering. The greater the coefficient $a$, the higher the tendency of shocks to persist. That is, volatility tends to rise when the standardized value of $\varepsilon_{t-1}\left(\left|\frac{\varepsilon_{t-1}}{\sqrt{h_{t-1}}}\right|\right)$ is larger and vice versa. Instead of using the value of $\varepsilon_{t-1}^{2}$, the EGARCH specification uses the level of standardized value of $\varepsilon_{t-1}$ which has a natural interpretation of the size and persistence of shocks.

$\gamma$ is the scale of the asymmetric volatility. If the coefficient, $\gamma$, is significant and negative, it indicates the presence of leverage effect. The leverage effect refers to the negative correlation between an asset return and its volatility implying that negative shocks (or bad news) generate larger volatility than positive shocks (or good news). If $\frac{\varepsilon_{t-1}}{\sqrt{h_{t-1}}}$ is positive (good news or positive shocks), the effect of the shock on the log of the conditional variance is $\gamma+\alpha$. If $\frac{\varepsilon_{t-1}}{\sqrt{h_{t-1}}}$ is negative (bad news or negative shocks), the effect of the shock on the log of the conditional variance is $-\gamma+\boldsymbol{\alpha}$. However, if $\gamma$ is not significant, then there is no asymmetric volatility. If $\gamma>0$ and significant, this means that positive shocks increase the volatility more than negative shocks.

$\beta$ is the coefficient for the logged GARCH term $\left(\ln \left(h_{t-1}\right)\right)$ and indicates the persistence of shocks. The condition that $|\beta|<1$ is a sufficient condition for the existence of moments, for consistency and for asymptotic normality of the $\operatorname{EGARCH}(1,1)$ estimators (Chang et al., 2014).

$E R^{2}$ represents the volatility of exchange rate. Since the ER variable is calculated as the percentage change in exchange rate, the square of ER can be used as a proxy for the volatility of exchange rate (Kasman et al., 2011).

$I R^{2}$ represents the volatility of interest rate. Since the IR variable is calculated as the percentage change in interest rate, the square of IR can be used as a proxy for the volatility of interest rate (Kasman et al., 2011). 
$D_{\text {crisis }}$ represents the global financial crisis of 2008. It takes ones for the period of $04 / 30 / 2008$ to $12 / 02 / 2009$, it takes zero otherwise. The beginning of the crisis period is determined as the date that the negative effects of crisis first observed in the stock market prices in Turkey.

\subsection{Data}

In this study, the data subject to empirical analysis are obtained from two main sources, the electronic data delivery system of the Turkish Central Bank of Turkey and the Finnet Data Delivery System. The sample period of data is from January 3, 2002 to April 22, 2020. The time series in the dataset of daily stock prices of five insurance companies listed on the Borsa Istanbul (BIST), BIST insurance sector index (XSGRT), BIST100 market index, exchange rate and 2-years government bonds. Exchange rate variable is calculated as equally weighted average of the US Dollar and the Euro prices of Turkish Lira. The insurance companies included in the dataset involve AKGRT, ANHYT, ANSGR, GUSGR, and RAYSG and they are determined by data availability. In the calculation of return variables, exchange rate return $\left(E R_{t}\right)$, interest rate return $\left(I R_{t}\right)$, market return $\left(M R_{t}\right)$ and stock returns of insurance companies $\left(R_{t}\right)$ are calculated by taking the first difference in log prices as $R_{t}=\left[\ln \left(P_{t}\right)-\ln \left(P_{t-1}\right)\right] * 100$, where $P_{t}$ and $P_{t-1}$ are daily closing prices at time $\mathrm{t}$ and $\mathrm{t}-1$ respectively.

\subsection{Unit Root Test}

As a first step in the analysis of stock the empirical model given in equation 4, the stationarity of the data is tested. It is well known that regression with nonstationary variables may lead to spurious regression invalidating most of the standard empirical results (Engle \& Granger, 1987; Enders, 2015). Furthermore, the GARCH-type models are stationary models. For these reasons, as a first step to estimating insurance stock return model given in equations 1 and 2, the integration level of the variables of interest are determined by using the Augmented Dickey-Fuller (ADF) test and Phillips-Perron unit root tests (Dickey \& Fuller, 1981; Phillips \& Perron, 1988). For each of the variables, the ADF and PP 
tests are conducted with intercept, and trend in the underlying Phillip-Perron and Dickey-Fuller regressions. Table 1 presents the results obtained from the ADF and PP unit root tests at level and at first differences. Examination of the results in Table 1 indicates that the null hypothesis of a unit root could not be rejected at $1 \%$ level of significance for each of the variables. This implies that the variables subject to empirical analysis are non-stationary and integrated at level one. However, the last two columns of Table 1 show that the null hypothesis of a unit root is rejected at $1 \%$ level of significance for differenced variables indicating that they are stationary at first difference.

Table 1. Unit Root Test Results

\begin{tabular}{|c|c|c|c|c|c|c|}
\hline & \multicolumn{4}{|c|}{ At Level } & \multicolumn{2}{c|}{ At First Difference } \\
\hline Variables & ADF $\left(\tau_{\mu}\right)$ & $\operatorname{ADF}\left(\tau_{\mu+t}\right)$ & $\operatorname{PP}\left(\tau_{\mu}\right)$ & $\operatorname{PP}\left(\tau_{\mu+t}\right)$ & $\operatorname{ADF}\left(\tau_{\mu}\right)$ & $\operatorname{PP}\left(\tau_{\mu}\right)$ \\
\hline IR & $-2.6321^{\star \star \star}$ & -2.0114 & -2.5630 & -2.0905 & $-72.8171^{\star}$ & $-72.7632^{\star}$ \\
\hline ER & 1.364981 & -0.7078 & 1.357733 & -0.8826 & $-48.5037^{\star}$ & $-62.0707^{\star}$ \\
\hline XU100 & -1.4876 & -2.0213 & -1.4879 & -2.0299 & $-67.1624^{\star}$ & $-67.1602^{\star}$ \\
\hline XSGRT & -1.2108 & -2.1086 & -1.2540 & -2.2315 & $-63.6708^{\star}$ & $-63.8847^{\star}$ \\
\hline AKGRT & -0.9141 & -2.4457 & -0.9185 & -2.4080 & $-64.7394^{\star}$ & $-64.6907^{\star}$ \\
\hline ANHYT & -1.2935 & -2.1389 & -1.3060 & -2.3789 & $-64.5940^{\star}$ & $-65.0937^{\star}$ \\
\hline ANSGR & -0.8113 & -2.0058 & -0.8373 & -2.0916 & $-46.1671^{\star}$ & $-68.2486^{\star}$ \\
\hline GUSGR & -2.2168 & -2.4795 & -2.2329 & -2.5100 & $-67.3148^{\star}$ & $-67.3204^{\star}$ \\
\hline RAYSG & -1.0419 & -1.4644 & -1.0164 & -1.4315 & $-63.8798^{\star}$ & $-63.8116^{\star}$ \\
\hline
\end{tabular}

Note: ADF and PP refer to the Augmented Dickey-Fuller (1981) and Phillips-Perron (1988) unit root tests. The subscripts, $\tau_{\boldsymbol{\mu}}$ and $\tau_{\boldsymbol{\mu}+\mathrm{t}}$ indicate unit root test with drift and unit root test with drift and trend respectively. The lag lengths in the ADF and PP regressions are determined by the Schwarz Information Criteria (SIC). Asterisks ( $\left.{ }^{*}, * \star, * \star *\right)$ show the $1 \%, 5 \%$, and $10 \%$ the level of significance.

Having determined that variables become stationary at first difference, first differences are used in the estimation of the empirical model. Table 2 provides the descriptive statistics for each of the five insurance stocks, exchange rate returns (ER), interest rate changes and market return variables. Investigation of Table 2 shows that the mean returns for insurance companies' stock returns are positive and ranging from 0.051 to 0.083 . Volatility of stock returns measured by standard deviation ranges from $1.784 \%$ for market return to $3.313 \%$ RAYSG. However, the volatility of exchange rate seems to be relatively small $(0.838 \%)$ compared to volatilities in stock returns and interest rate. Table 2 also shows that the volatility of 2-year treasury bills is $1.964 \%$. Furthermore, the results in Table 2 
show that all series subject to empirical analysis have a skewed and leptokurtic distribution rather than normal distribution.

Table 2. Descriptive Statistics

\begin{tabular}{|l|c|c|c|c|c|c|c|c|c|}
\hline & IR & ER & MR & XSGRT & AKGRT & ANHYT & ANSGR & GUSGR & RAYSG \\
\hline Mean & -0.042 & 0.036 & 0.042 & 0.061 & 0.083 & 0.082 & 0.080 & 0.051 & 0.070 \\
\hline Median & -0.018 & 0.000 & 0.095 & 0.079 & 0.000 & 0.000 & 0.000 & 0.000 & 0.000 \\
\hline Maximum & 20.211 & 14.340 & 12.127 & 11.478 & 32.126 & 17.768 & 13.062 & 18.232 & 19.863 \\
\hline Minimum & -26.085 & -9.041 & -13.341 & -12.961 & -13.778 & -17.035 & -16.990 & -19.692 & -22.137 \\
\hline Std. Dev. & 1.964 & 0.838 & 1.784 & 1.926 & 2.558 & 2.498 & 2.161 & 2.812 & 3.313 \\
\hline Skewness & -0.181 & 1.392 & -0.189 & -0.355 & 0.486 & 0.026 & 0.006 & 0.137 & 0.590 \\
\hline Kurtosis & 25.198 & 31.849 & 7.634 & 8.334 & 11.583 & 8.368 & 8.231 & 9.215 & 10.228 \\
\hline Jarque-Bera & $94451^{*}$ & $160972^{*}$ & $4143^{*}$ & $5549 *$ & $14298^{*}$ & $5523^{*}$ & $5243^{*}$ & $7417^{*}$ & $10279^{*}$ \\
\hline Observations & 4599 & 4599 & 4599 & 4599 & 4599 & 4599 & 4599 & 4599 & 4599 \\
\hline
\end{tabular}

Note: Asterisk (*) shows the $1 \%$ level of significance. JB shows Jarque-Bera normality test.

\section{Empirical Findings}

To investigate the impact of interest rate, exchange rate and market risk on Turkish insurance companies' returns, we first estimated an empirical insurance return model (Equation 1) by the ordinary least square (OLS) for individual insurance companies and insurance sector index. Table 3 presents the results obtained from OLS regressions. Investigating the results indicate that while the market and interest rate risk have a significant effect on insurance company's stock returns in almost all cases, the effect of exchange rate risk on the insurance returns is not statistically significant. The coefficient of interest rate risk variable is negative statistically significant for all cases except for the company RAYSB. The results show that most of the change in the individual insurance company and insurance portfolio returns are explained by the overall market returns. The diagnostic statistics associated with regression models in Table 3 indicate that although error terms are not correlated over time (no autocorrelation), there is a changing variance (heteroscedasticity) problems in error terms. The ARCH heteroscedasticity tests show that variances are not constant, and they are linked and changing over time making the OLS estimators inefficient and standard t-test and F-tests unreliable. 
Table 3. Insurance Stock Returns: OLS Estimation Results

\begin{tabular}{|c|c|c|c|c|c|c|}
\hline Coefficients & XSGRT & AKGRT & ANHYT & ANSGR & GUSGR & RAYSG \\
\hline$a_{0}$ & $\begin{array}{c}0.0245 \\
(0.0185)\end{array}$ & $\begin{array}{c}0.0434 \\
(0.0291) \\
\end{array}$ & $\begin{array}{c}0.0464 \\
(0.0299) \\
\end{array}$ & $\begin{array}{c}0.0465^{\star * *} \\
(0.0246)\end{array}$ & $\begin{array}{c}0.0147 \\
(0.0355)\end{array}$ & $\begin{array}{c}0.0371 \\
(0.0449)\end{array}$ \\
\hline$a_{1}$ & $\begin{array}{c}0.0094 \\
(0.0221)\end{array}$ & $\begin{array}{c}0.0005 \\
(0.0347) \\
\end{array}$ & $\begin{array}{l}-0.0442 \\
(0.0357) \\
\end{array}$ & $\begin{array}{l}-0.0150 \\
(0.0294)\end{array}$ & $\begin{array}{c}0.0195 \\
(0.0424) \\
\end{array}$ & $\begin{array}{c}0.0270 \\
(0.0536)\end{array}$ \\
\hline$a_{2}$ & $\begin{array}{c}-0.0477^{\star} \\
(0.0100)\end{array}$ & $\begin{array}{c}-0.0405^{\star} \\
(0.0157)\end{array}$ & $\begin{array}{c}-0.0953^{*} \\
(0.0162)\end{array}$ & $\begin{array}{c}-0.0397 * \\
(0.0133) \\
\end{array}$ & $\begin{array}{c}-0.0546 * \\
(0.0192)\end{array}$ & $\begin{array}{l}-0.0330 \\
(0.0243)\end{array}$ \\
\hline$a_{3}$ & $\begin{array}{l}0.8006^{\star} \\
(0.0110)\end{array}$ & $\begin{array}{l}0.8997 * \\
(0.0173)\end{array}$ & $\begin{array}{l}0.7788^{*} \\
(0.0178)\end{array}$ & $\begin{array}{l}0.7565^{\star} \\
(0.0146)\end{array}$ & $\begin{array}{l}0.7982^{\star} \\
(0.0211)\end{array}$ & $\begin{array}{l}0.7286^{*} \\
(0.0267)\end{array}$ \\
\hline$R^{2}$ & 0.5767 & 0.4075 & 0.3430 & 0.4064 & 0.2705 & 0.1591 \\
\hline $\mathrm{SIC}$ & 3.2956 & 4.1996 & 4.2555 & 3.8638 & 4.5969 & 5.0667 \\
\hline F-statistic & $2088.80 *$ & $1055.20 *$ & $801.29 *$ & $1050.50 *$ & $569.26^{*}$ & $290.94^{*}$ \\
\hline DW & 1.9191 & 1.9622 & 1.9462 & 2.0958 & 1.9485 & 1.9085 \\
\hline $\mathrm{ARCH}(1)$ & $312.71^{*}$ & $15.33^{* *}$ & $181.84^{*}$ & $339.05^{*}$ & $312.69 *$ & 569.11* \\
\hline
\end{tabular}

Note: Coefficients refer to the estimates of the following stock returns model: $R_{t}=a_{0}+a_{1} E R_{t}+a_{2} / R_{t}+a_{3} M R_{t}+\varepsilon_{t} R^{2}$, SIC, F-Statistic, DW, ARCH(1) stand for adjusted R-square, Schwarz Information Criterion, overall significance test, Durbin-Watson autocorrelation test and ARCH heteroscedasticity test (Chi-Square) respectively. Numbers in parentheses indicate standard errors. ${ }^{*},{ }^{* *},{ }^{* * *}$ indicate the significance level at $1 \%, 5 \%$ and $10 \%$ respectively.

As mentioned above, the suitable model is the GARCH type models in the presence of clustering volatility in the series. To this end, this study employed the insurance stock return model with conditional variance that assumes the EGARCH specification given in Equations (1) and (2) to model the time varying properties of the return series. Table 4 presents the results obtained from estimating the mean (Equation 1) and variance equation (Equation 2) simultaneously using Maximum Likelihood method. The results in Table 4 provide rich information about the mean and volatility determinants of insurance companies' stock returns.

First, exchange rate risk does not seem to be an important determinant of the insurance sector and insurance firms' stock returns except for the company RAYGS. For RAYSG Company, the coefficient of exchange rate risk is positive and statistically significant indicating that the stock return and exchange rate move together. Second, the results also indicate that the second systematic risk component, interest rate risk, has a negative and statistically significant effect on stock returns of insurance portfolio and insurance companies except RAYGS. Both of these findings should not come as a surprise that the insurance companies invest their funds into financial assets in domestic currency rather than financial instruments in foreign 
currency. However, the findings about the RAYGS Company imply that the share of its assets exposed to foreign currency is higher than its domestic currency dominated assets and liabilities. It is also worth mentioning that the size of the interest rate risk coefficient differs significantly among companies ranging from -0.0198 to -0.0779 implying the importance of heterogeneity in the insurance stock returns-interest rate relationship. Third, the impact of market returns on insurance companies' stock returns are significant in all cases and larger in magnitude ranging from 0.6167 to 0.8333 . This indicates that a great amount of conditional insurance stock returns are explained by market return.

Table 4. EGARCH Model

\begin{tabular}{|c|c|c|c|c|c|c|}
\hline & XSGRT & AKGRT & ANHYT & ANSGR & GUSGR & RAYSG \\
\hline Coefficients & \multicolumn{6}{|c|}{ Mean Equation } \\
\hline$a_{0}$ & $\begin{array}{l}0.0485^{\star} \\
(0.0166)\end{array}$ & $\begin{array}{c}0.0432 \\
(0.0282)\end{array}$ & $\begin{array}{l}0.0578 * \star \\
(0.0250)\end{array}$ & $\begin{array}{l}0.0579 * \\
(0.0209)\end{array}$ & $\begin{array}{c}0.0151 \\
(0.0289)\end{array}$ & $\begin{array}{c}0.0087 \\
(0.0353)\end{array}$ \\
\hline$a_{1}$ & $\begin{array}{c}0.0052 \\
(0.0202)\end{array}$ & $\begin{array}{l}-0.0447 \\
(0.0329)\end{array}$ & $\begin{array}{l}-0.0270 \\
(0.0294)\end{array}$ & $\begin{array}{c}0.0047 \\
(0.0253)\end{array}$ & $\begin{array}{c}-0.0374 \\
(0.0308)\end{array}$ & $\begin{array}{c}0.1751^{\star} \\
(0.0386)\end{array}$ \\
\hline$a_{2}$ & $\begin{array}{c}-0.0449 * \\
(0.0083)\end{array}$ & $\begin{array}{c}-0.0414^{\star} \\
(0.0160)\end{array}$ & $\begin{array}{c}-0.0779 * \\
(0.0124)\end{array}$ & $\begin{array}{c}-0.0198 * \star \star \\
(0.0116)\end{array}$ & $\begin{array}{c}-0.0379 * \\
(0.0154)\end{array}$ & $\begin{array}{l}-0.0242 \\
(0.0194)\end{array}$ \\
\hline$a_{3}$ & $\begin{array}{c}0.6685^{\star} \\
(0.0089)\end{array}$ & $\begin{array}{l}0.8333^{\star} \\
(0.0136)\end{array}$ & $\begin{array}{l}0.6358^{*} \\
(0.0136)\end{array}$ & $\begin{array}{l}0.6167^{*} \\
(0.0105)\end{array}$ & $\begin{array}{l}0.7560 * \\
(0.0135) \\
\end{array}$ & $\begin{array}{l}0.6365^{\star} \\
(0.0175)\end{array}$ \\
\hline Coefficients & \multicolumn{6}{|c|}{ Variance Equation } \\
\hline$\omega$ & $\begin{array}{l}-0.1171 * \\
(0.0071)\end{array}$ & $\begin{array}{l}-0.0142 \\
(0.0176)\end{array}$ & $\begin{array}{l}-0.1069 * \\
(0.0063)\end{array}$ & $\begin{array}{c}-0.0972 * \\
(0.0058)\end{array}$ & $\begin{array}{l}-0.0108 \\
(0.0102)\end{array}$ & $\begin{array}{l}0.1269 * \\
(0.0137)\end{array}$ \\
\hline$a$ & $\begin{array}{c}0.1668^{*} \\
(0.0100)\end{array}$ & $\begin{array}{l}0.3318^{*} \\
(0.0124)\end{array}$ & $\begin{array}{c}0.1910 * \\
(0.0096)\end{array}$ & $\begin{array}{c}0.1779 * \\
(0.0094)\end{array}$ & $\begin{array}{l}0.3169 * \\
(0.0101)\end{array}$ & $\begin{array}{l}0.4221^{*} \\
(0.0119)\end{array}$ \\
\hline$\gamma$ & $\begin{array}{c}0.0176^{\star} \\
(0.0048)\end{array}$ & $\begin{array}{l}0.0254^{\star *} \\
(0.0108)\end{array}$ & $\begin{array}{c}0.0078 \\
(0.0059)\end{array}$ & $\begin{array}{l}-0.0028 \\
(0.0064)\end{array}$ & $\begin{array}{l}0.0872 * \\
(0.0074)\end{array}$ & $\begin{array}{l}0.0906 * \\
(0.0089)\end{array}$ \\
\hline$\beta$ & $\begin{array}{c}0.9729 * \\
(0.0036)\end{array}$ & $\begin{array}{l}0.8196 * \\
(0.0149)\end{array}$ & $\begin{array}{c}0.9715^{\star} \\
(0.0029)\end{array}$ & $\begin{array}{l}0.9636 * \\
(0.0031)\end{array}$ & $\begin{array}{l}0.8536^{\star} \\
(0.0056)\end{array}$ & $\begin{array}{c}0.7855^{\star} \\
(0.0084)\end{array}$ \\
\hline$\delta$ & $\begin{array}{l}0.0031 * * \\
(0.0015)\end{array}$ & $\begin{array}{c}0.0048 \\
(0.0037)\end{array}$ & $\begin{array}{l}0.0035^{\star} \\
(0.0012)\end{array}$ & $\begin{array}{c}0.0018 \\
(0.0014)\end{array}$ & $\begin{array}{l}0.0086^{*} \\
(0.0022)\end{array}$ & $\begin{array}{c}0.0181^{*} \\
(0.0024)\end{array}$ \\
\hline$\theta$ & $\begin{array}{l}-0.0004 \\
(0.0003)\end{array}$ & $\begin{array}{c}0.0008 * * * \\
(0.0004)\end{array}$ & $\begin{array}{c}0.0000 \\
(0.0003)\end{array}$ & $\begin{array}{c}-0.0006 * \star \\
(0.0003)\end{array}$ & $\begin{array}{l}0.0033^{*} \\
(0.0003)\end{array}$ & $\begin{array}{c}0.0006 \\
(0.0006)\end{array}$ \\
\hline
\end{tabular}

Note: Coefficients refer to the estimates of the mean and variance equations of the following the EGARCH(1.1) model: Mean Equation: $R_{t}=a_{0}+a_{1} E R_{t}+a_{2} I R_{t}+a_{3} M R_{t}+\varepsilon_{t}$ Variance Equation: $\ln \left(h_{t}\right)=\omega+\alpha \frac{\varepsilon_{t-1}}{\sqrt{\boldsymbol{k}_{-1}}}+\gamma \frac{\varepsilon_{t-1}}{\sqrt{\boldsymbol{h}_{t-1}}}+\beta \ln \left(h_{t-1}\right)+$ $\delta E R^{2}+\theta I R^{2}$. Numbers in parentheses indicate standard errors. ${ }^{*}, * *, * * *$ indicate the significance level at $1 \%, 5 \%$ and $10 \%$ respectively.

The findings on the variance equation in Table 4 also reveal valuable information about the size and the determinants of volatility in insurance stock 
returns. First, the fact that the time dependent and time-independent components of volatility are statistically significantly different from zero in almost all cases imply that both components are important in determining volatility in the insurance sector. While the time dependent components of volatility, $\mathrm{ARCH}(\alpha)$ and $\mathrm{GARCH}(\beta)$ coefficients, are significant in all cases, the time independent component of volatility (constant term in variance equation), $\omega$, is significant in only four out of six cases. Secondly, the coefficient of ARCH effect $\left(\frac{\varepsilon_{t-1}}{\sqrt{h_{t-1}}} \mid\right), a$, is significant and positive in all cases implying that the volatility changes over time (volatility clustering exists). The size of the $a$ also indicate the tendency of past innovation to persist. In this sense, the persistence degree of past innovation, ranging from 0.1668 to 0.4221 , seems to be moderate. It is worth mentioning that while the tendency of shocks to persist assumes the lowest coefficient for the insurance portfolio, it differs significantly among insurance companies. This implies that the persistency level of shocks on the conditional variance varies significantly across firms. Thirdly, examination of Table 4 shows that the GARCH coefficients $(\beta$ 's) are statistically significant, positive, and less than one (ranging from 0.7855 to 0.9729 ) in all cases. This means that the current volatility is closely linked to past volatility and the persistence of volatility is very high and it takes a long time for volatility to dissipate or to die out. For example, using the half-life formula of $\ln (0.5) / \ln (\beta)$, it can be shown that the half-life of a unit shock for the persistence coefficient of $0.9729(0.7855)$ is equal to 25.3 (2.87) days. More importantly, finding that is $\beta$ less than one indicate that the conditional variance equation is stable since the stability and stationarity condition for the EGARCH requires that $|\beta|<1$. The findings on $\alpha$ and $\beta$ given above indicate that current conditional volatility is changing over time and it is a function of both past innovations and past volatility. Moreover, the finding that $\alpha$ is smaller than $\beta$ shows that the current conditional volatility is more sensitive to old news (GARCH effect) than recent surprises (ARCH effect).

Fourthly, the coefficients of standardized $\varepsilon_{(t-1)}, \gamma$, are significant and positive in 4 out of 6 cases and they are insignificant in the remaining two cases. As explained in the 
model section, the sign of $\gamma$ denotes whether shocks have an asymmetric or leverage effect on current volatility. The positive and significant $\gamma$ coefficient indicates that positive and negative surprises have an asymmetric effect on volatility implying that positive innovations (good news such as a market) have a larger impact on current conditional variance (current volatility of returns) than negative innovations (bad news such as market stagnation) of the same magnitude. The insignificant $\gamma^{\prime}$, however, show that the impact of positive and negative news have a symmetric (an equal) effect on current volatility. The effect of the shock on the log of the conditional variance ranges from 0.1844 to $0.512(\gamma+a)$ for good news or positive shocks and it ranges 0.1492 to $0.3315(-\gamma+\alpha)$ for bad news or negative shocks.

Fifthly, exchange rate volatility and interest rate volatility plays an important role in determining the current volatility of stock returns for insurance portfolio and insurance firms. While the coefficient of exchange rate volatility is significant in four out of six cases, interest rate volatility is significant in three out of six cases. These findings reveal very important information about the impact of exchange rate and interest rate risk on insurance companies' stock returns. Considering the determinants of stock returns in the mean equation, one can reach a conclusion that exchange rate risk plays an important role in determining the volatility of insurance stock returns while it has no effect on mean stock returns of insurance companies. However, the exact opposite is true for the interest rate risk variable. While the interest rate risk has a significant and negative effect on stock returns of insurance companies, it has only a marginal effect on the volatility of stock returns in the insurance sector.

To investigate the impact of 2008 crisis impact on the findings presented in Table 5, we also estimated the insurance stock returns model extended with a 2008 crisis dummy variable. Table 5 presents the results obtained from estimating the extended $\operatorname{EGARCH}(1,1)$ model given in equations 3 and 4 . As mentioned in the model section, 2008 crisis dummy takes ones during the crisis years of 20082009 and zeros otherwise. Table 5 sheds lights mainly on two important points. The first one is about the coefficient estimates related to mean and variance equations of the insurance returns model. Inspection of Table 4 and Table 5 
indicates that the estimation results related to the mean and variance equations provided in both tables are similar to each other. The results are similar in terms of significance, size, and signs of estimates of parameters. In this sense, it seems that adding a crisis dummy to the model has no effect on comments given above.

Table 5. EGARCH Model with Crisis Dummy

\begin{tabular}{|c|c|c|c|c|c|c|}
\hline & XSGRT & AKGRT & ANHYT & ANSGR & GUSGR & RAYSG \\
\hline Coefficients & \multicolumn{6}{|c|}{ Mean Equation } \\
\hline$a_{0}$ & $\begin{array}{l}0.0484^{*} \\
(0.0166)\end{array}$ & $\begin{array}{c}0.0445 \\
(0.0282) \\
\end{array}$ & $\begin{array}{l}0.0573^{\star *} \\
(0.0251)\end{array}$ & $\begin{array}{c}0.0567^{*} \\
(0.0209) \\
\end{array}$ & $\begin{array}{c}0.0165 \\
(0.0290) \\
\end{array}$ & $\begin{array}{c}0.0135 \\
(0.0350) \\
\end{array}$ \\
\hline$a_{1}$ & $\begin{array}{c}0.0053 \\
(0.0202) \\
\end{array}$ & $\begin{array}{l}-0.0400 \\
(0.0326) \\
\end{array}$ & $\begin{array}{l}-0.0267 \\
(0.0295)\end{array}$ & $\begin{array}{c}0.0035 \\
(0.0257) \\
\end{array}$ & $\begin{array}{l}-0.0366 \\
(0.0308) \\
\end{array}$ & $\begin{array}{c}0.1712^{*} \\
(0.0386)\end{array}$ \\
\hline$a_{2}$ & $\begin{array}{c}-0.0449 * \\
(0.0084)\end{array}$ & $\begin{array}{c}-0.0413^{*} \\
(0.0161)\end{array}$ & $\begin{array}{c}-0.0776^{*} \\
(0.0125)\end{array}$ & $\begin{array}{c}-0.0202^{* * *} \\
(0.0117)\end{array}$ & $\begin{array}{c}-0.0381^{* *} \\
(0.0154)\end{array}$ & $\begin{array}{l}-0.0235 \\
(0.0201)\end{array}$ \\
\hline$a_{3}$ & $\begin{array}{c}0.6712^{*} \\
(0.0089) \\
\end{array}$ & $\begin{array}{l}0.8305^{\star} \\
(0.0138) \\
\end{array}$ & $\begin{array}{l}0.6363^{*} \\
(0.0136) \\
\end{array}$ & $\begin{array}{c}0.6173^{*} \\
(0.0105) \\
\end{array}$ & $\begin{array}{c}0.7571^{*} \\
(0.0136) \\
\end{array}$ & $\begin{array}{l}0.6401^{*} \\
(0.0180) \\
\end{array}$ \\
\hline Coefficients & \multicolumn{6}{|c|}{ Variance Equation } \\
\hline$\omega$ & $\begin{array}{c}-0.1202^{*} \\
(0.0075) \\
\end{array}$ & $\begin{array}{l}-0.0003 \\
(0.0189) \\
\end{array}$ & $\begin{array}{l}-0.1062^{\star} \\
(0.0064) \\
\end{array}$ & $\begin{array}{c}-0.0980^{*} \\
(0.0059) \\
\end{array}$ & $\begin{array}{l}-0.0068 \\
(0.0103) \\
\end{array}$ & $\begin{array}{l}0.1282^{*} \\
(0.0137) \\
\end{array}$ \\
\hline$a$ & $\begin{array}{l}0.1709^{*} \\
(0.0106) \\
\end{array}$ & $\begin{array}{l}0.3262^{*} \\
(0.0128) \\
\end{array}$ & $\begin{array}{c}0.1925^{\star} \\
(0.0098) \\
\end{array}$ & $\begin{array}{c}0.1824^{*} \\
(0.0096) \\
\end{array}$ & $\begin{array}{l}0.3133^{\star} \\
(0.0103) \\
\end{array}$ & $\begin{array}{c}0.4161^{*} \\
(0.0118) \\
\end{array}$ \\
\hline$\gamma$ & $\begin{array}{l}0.0195^{\star} \\
(0.0050)\end{array}$ & $\begin{array}{l}0.0288^{*} \\
(0.0109) \\
\end{array}$ & $\begin{array}{c}0.0083 \\
(0.0060) \\
\end{array}$ & $\begin{array}{l}-0.0038 \\
(0.0066) \\
\end{array}$ & $\begin{array}{l}0.0901^{*} \\
(0.0075)\end{array}$ & $\begin{array}{l}0.0950^{*} \\
(0.0089)\end{array}$ \\
\hline$\beta$ & $\begin{array}{l}0.9668^{*} \\
(0.0043)\end{array}$ & $\begin{array}{l}0.8067^{*} \\
(0.0171)\end{array}$ & $\begin{array}{l}0.9693^{*} \\
(0.0031)\end{array}$ & $\begin{array}{c}0.9595^{\star} \\
(0.0034)\end{array}$ & $\begin{array}{c}0.8511^{*} \\
(0.0056)\end{array}$ & $\begin{array}{c}0.7827^{*} \\
(0.0085)\end{array}$ \\
\hline$\delta$ & $\begin{array}{c}0.0028^{* * *} \\
(0.0015)\end{array}$ & $\begin{array}{c}0.0038 \\
(0.0039) \\
\end{array}$ & $\begin{array}{l}0.0033^{*} \\
(0.0013)\end{array}$ & $\begin{array}{c}0.0010 \\
(0.0018)\end{array}$ & $\begin{array}{l}0.0080^{*} \\
(0.0023) \\
\end{array}$ & $\begin{array}{c}0.0156^{*} \\
(0.0024) \\
\end{array}$ \\
\hline$\theta$ & $\begin{array}{l}-0.0002 \\
(0.0003) \\
\end{array}$ & $\begin{array}{c}0.0009 * \star \star \\
(0.0004)\end{array}$ & $\begin{array}{c}0.0001 \\
(0.0003)\end{array}$ & $\begin{array}{c}-0.0005^{\star \star *} \\
(0.0003) \\
\end{array}$ & $\begin{array}{l}0.0034^{\star} \\
(0.0003)\end{array}$ & $\begin{array}{c}0.0007 \\
(0.0006) \\
\end{array}$ \\
\hline$\lambda$ & $\begin{array}{l}0.0264^{*} \\
(0.0084)\end{array}$ & $\begin{array}{c}0.1112^{*} \\
(0.0229)\end{array}$ & $\begin{array}{c}0.0144 \\
(0.0091)\end{array}$ & $\begin{array}{l}0.0236^{*} \\
(0.0079)\end{array}$ & $\begin{array}{c}0.0432^{* *} \\
(0.0201)\end{array}$ & $\begin{array}{c}0.1491^{*} \\
(0.0155)\end{array}$ \\
\hline
\end{tabular}

Note: Coefficients refer to the estimates of the mean and variance equations of the following the EGARCH(1.1) model: Mean Equation: $R_{t}=a_{0}+a_{1} E R_{t}+a_{2} I R_{t}+a_{3} M R_{t}+\varepsilon_{t}$ Variance Equation: $\ln \left(h_{t}\right)=\omega+\alpha \frac{\varepsilon_{t-1}}{\sqrt{\boldsymbol{k}_{t-1}}}+\gamma \frac{\varepsilon_{t-1}}{\sqrt{\boldsymbol{h}_{t-1}}}+\beta \ln \left(h_{t-1}\right)+\delta E R^{2}+\theta I R^{2}$

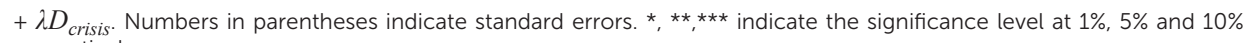
respectively.

The second point that Table 5 makes is about the effect of crisis dummy on the volatility of insurance returns. Examination of Table 4 shows that the coefficients of crisis dummy are significant and positive in five out of six cases. This indicates that the volatility of insurance portfolio's and insurance companies' stock returns has risen significantly during the financial crisis of 2008 compared to the rest of 
the sample period. Moreover, the size of the coefficient of crisis dummy is equal to 0.0264 and it varies significantly across insurance companies ranging from 0.0264 to 0.1491 . The latter result confirms that the firm level analysis of stock returns provide richer information about the determinants of stock returns compared to sectoral level analysis.

\section{Conclusion}

This study examined the impact of exchange rate, interest rate and market risk factors on the stock returns of insurance portfolio and insurance companies listed in Borsa İstanbul (İstanbul Stock Exchange) in Turkey. In the analysis of the relationship between insurance stock returns and insurance sector's risk factors, this study employed the EGARCH (1.1) model. The findings of this study shed light on the dynamic and time varying nature of the relationship among stock returns, exchange rate, interest rate and market returns mainly five ways.

First, exchange rate volatility and interest rate volatility play an important role in determining the current volatility of stock returns for insurance portfolio and insurance firms. While the coefficient of exchange rate volatility is significant in four out of six cases, interest rate volatility is significant in three out of six cases. These findings reveal very important information about the impact of exchange rate and interest rate risk on insurance companies' stock returns. Considering the determinants of stock returns in the mean equation, these finding suggest that exchange rate risk plays an important role in determining the volatility of insurance stock returns while it has no effect on mean stock returns of insurance companies. However, the exact opposite is true for the interest rate risk variable. While the interest rate risk has a significant and negative effect on stock returns of insurance companies, it has only a marginal effect on the volatility of stock returns in the insurance sector.

Second, the volatility of insurance stock returns is persistent, changes over time and differs significantly among insurance companies. The current volatility of insurance stock returns is closely linked to past volatility and the persistence of volatility is very high and it takes a long time for volatility to dissipate or to die 
out. Thirdly, current conditional volatility is changing over time and it is a function of both past innovations and past volatility. Moreover, the finding that $a$ is smaller than $\beta$ shows that the current conditional volatility is more sensitive to old news (GARCH effect) than recent surprises (ARCH effect).

Fourthly, positive and negative news have an asymmetric effect on volatility implying that positive innovations (good news such as a market) have a larger impact on current conditional variance (current volatility of returns) than negative innovations (bad news such as market stagnation) of the same magnitude. Fifthly, the coefficients of crisis dummy are significant and positive in five out of six cases. This indicates that the volatility of insurance portfolio's and insurance companies' stock returns has risen significantly during the financial crisis of 2008 compared to the rest of the sample period. Moreover, the size of the coefficient of crisis dummy is equal to 0.0264 and it varies significantly across insurance companies ranging from 0.0264 to 0.1491 . The latter result confirms that the firm level analysis of stock returns provide richer information about the determinants of stock returns compared to sectoral level analysis.

\footnotetext{
Peer-review: Externally peer-reviewed.

Conflict of Interest: The author has no conflict of interest to declare.

Grant Support: The author declared that this study has received no financial support.

Hakem Değerlendirmesi: Dış bağımsız.

Çıkar Çatışması: Yazar çıkar çatışması bildirmemiştir.

Finansal Destek: Yazar bu çalışma için finansal destek almadığını beyan etmiştir.
}

\section{References/Kaynakça}

Mouna, A. \& Anis, J. (2016) Market, interest rate, and exchange rate risk effects on financial stock returns during the financial crisis: AGARCH-M approach, Cogent Economics \& Finance, 4(1), 1125332. DOI: 10.1080/23322039.2015.1125332.

Bach, B. \& Ando, A. (1957). The redistribution of effects of inflation. The Review of Economics and Statistics, 3, 1-13.

Bollerslev, T. (1986). Generalized autoregressive conditional heteroskedasticity. Journal of Econometrics, 31, 307-327.

Brewer, E., Carson, J., Elyasiani, E., Mansur, I., \& Scott, W. (2007). Interest rate risk and equity values of life insurance companies: A GARCH-M model. Journal of Risk and Insurance, 74, 401-423. 
Carson, J. M., Elyasiani, E. \& Mansur, I. (2008) Market Risk, Interest Rate Risk, and Interdependencies in Insurer Stock Returns: A System-GARCH Model, Journal of Risk \& Insurance, 75(4), 873-891.

Çelik, I. E. (2019), Assessing the impact of bank risk factors on Turkish bank's stock returns using The EGARCH-M model, Üçüncü Sektör Sosyal Ekonomi Dergisi, 54(2), 811-827.

Chang, C. L., H. K. Hsu \& M. McAleer (2014) The impact of China on stock returns and volatility in the Taiwan tourism industry, North American Journal of Economics and Finance, 29, 381-401.

Çiçek, M. (2014). Türkiye'de faiz, döviz ve borsa: fiyat ve oynaklık yayılma etkileri, Ankara Üniversitesi SBF Dergisi, 65(2), 1-28.

De Sousa, A. M., Noriller, R. M., Huppes C. M., Vaz Lopes, A. C., Meurer, R. M. (2018). Relation between the macroeconomic variables and the stock return in companies of the finance and insurance sector from Latin American stock market, Revista Journal, Vol.12, N3, 20-30.

Dickey, D. \& Fuller W. (1981). likelihood ratio statistics for autoregressive time series with a unit root, Econometrica, 49, 1057-1072.

Dikko, H. G., Asiribo, O. E. \& Samson, A. (2015). Modelling Abrupt Shift in Time Series Using Indicator Variable: Evidence of Nigerian Insurance Stock, International Journal of Finance and Accounting, 2015, 4(2), 119-130.

Ekinci, A. (2016). The effect of credit and market risk on bank perforamance: evidence from Turkey, International Journal of Economics and Financial Issues, 6(2), 427-434.

Elyasiani, E., \& Mansur, I. (2005). The association between market and exchange rate risks and accounting variables: A GARCH model of the Japanese banking institutions, Review of Quantitative Finance and Accounting, 25(2), 183-206.

Elyasiani, E. \& Mansur, I., (1998). Sensitivity of bank stock returns distribution to changes in the level of volatility of interest rate: a GARCH-M model, Journal of Banking and Finance, 22, 535-563.

Enders, Walter (2015). Applied econometrics time series, John Wiley \& Sons Inc.

Engle R. F. \& Granger, C. W. J. (1987). Cointegration and error correction: representation, estimation and testing, Econometrica, 50, 987-1007.

Engle, R. F. (1982). Autoregressive conditional heteroscedasticity with estimates of the variance of United Kingdom inflation, Econometrica, 50(4), 987-1007.

Engle, R. F. and Ng, V. \& Rothschild, M., (1990). Asset pricing with a factor ARCH covariance structure: Empirical estimates for treasury bills, Journal of Econometrics, 45, 213-238.

Flannery, M. J., Hameed, A.S. \& Harjes, R. H. (1997). Asset pricing, time-varying risk premia and interest rate risk. Journal of Banking \& Finance, 21, 315-335.

Francq, C. \& Zakoian, J. M. (2019). GARCH models structure, statistical inference and financial applications, New Jersey: John Wiley \& Sons.

French, K., Ruback, R., \& Schwart, G. (1983). Effects of nominal contracting on stock returns, Journal of Political Economy, 91(1), 70-96.

Hamadu, D. \& A. Ibiwoye (2010). Modelling and forecasting the volatility of the daily returns of nigerian insurance stocks, International Business Research, 3(2), 106-116.

Hooy, C. W., Tan, H. B. \& Md Nassir, A. (2004). Risk sensitivity of bank stocks in Malaysia: empirical evidence across the Asian financial crisis, Asian Economic Journal, 18, 261-276. 
Jensen, T.K., Johnson, R. R. \& McNamara, M. J. (2019) Funding conditions and insurance stock returns: Do insurance stocks really benefit from rising interest rate regimes?, Risk Management and Insurance Review, 22, 367-391.

Kasman, S., Vardar, G. \& Tunç, G., (2011). The impact of interest rate and exchange rate volatility on bank's stock returns and volatility: Evidence from Turkey, Economic Modelling, 28, 1328-1334.

Katusiime, L. (2019). Investigating Spillover Effects between Foreign Exchange Rate Volatility and Commodity Price Volatility in Uganda, Economies 2019, 7, 1, https://www.mdpi.com/journal/economies.

Kessel, R. (1956). Inflation-caused wealth redistribution: a test of a hypothesis, The American Economic Review, 3, 128-141.

Mansur, I. \& Elyasiani, E. (1995). Sensitivity of bank equity returns to the level and volatility of interest rates, Managerial Finance, 21, 58-77.

Mechri, N., Ben Hamad, S., Peretti, C., Charf, S. (2018). The Impact of the Exchange Rate Volatilities on Stock Markets Dynamics: Evidence from Tunisia and Turkey, https://ssrn.com/ abstract=3304040 or http://dx.doi.org/10.2139/ssrn.3304040.

Merton, R. C. (1973). An intertemporal capital asset pricing model, Econometrica, 41, 867-887.

Nelson, D. B. (1991). Conditional heteroskedasticity in asset returns: A new approach, Econometrica, 59 (2), 347-370.

Olugbode, M., El-Masry, A. \& Pointon, J. (2014). Exchange rate and interest rate exposure of UK industries using first-order autoregressive exponential GARCH-in-Mean (EGARCH-M) approach, The Manchester School, 82(4), 409-464.

Özçiçek, Ö. (1997). Türkiye'de döviz kuru getirisi ve hisse senedi endeks getirileri oynaklıkları arası simetrik ve asimetrik ilişki, IMKB Dergisi, 10(37), 1-11.

Papadamou, S. \& Siriopoulos, C. (2014). Interest rate risk and the creation of the Monetary Policy Committee: Evidence from banks' and life insurance companies' stocks in the UK Journal of Economics and Business, 71 (2014) 45-67.

Phillips, P. C. B. \& Perron, P. (1988). Testing for a unit root in time series regression, Biometrika, 75, 335-346.

Ryan, S. \& Worthington, A. (2004). Market, interest rate and foreign exchange rate risk in Australian banking: a GARCH-M approach, International Journal of Applied Business and Economic Research, 2(2), 81-103.

Saunders, A. \& Yourougou, P. (1990). Are banks special? The separation of banking from commerce and interest rate risk, Journal of Economics and Business, 42, 171-182.

Sehgal, S. \& Agrawal, T. J. (2017). Bank risk factors and changing risk exposures in the pre- and post-financial crisis periods: An empirical study for India, Management and Labour Studies, 42(4), 356-378.

Yourougou, P. (1990). Interest rate and the pricing of depository financial intermediary common stock: empirical evidence, Journal of Banking \& Finance, 14, 803-820. 
